\title{
Neo-Industrial Content of Economic Growth: Criteria, Indicators, Factors and Prospective Assessment for Russia
}

\author{
Ludmila Aleksandrovna Kormishkina, Evgeniy Danilovich Kormishkin and Dmitry Aleksandrovich \\ Koloskov* \\ Ogarev Mordovia State University, Saransk, Respublika Mordoviya - 430001, Russia; \\ kormishkinala@mail.ru, econtheor@mail.ru,kda1977@mail.ru
}

\begin{abstract}
Background/Objectives: The study investigates the problem of economic growth from the perspectives of neo-industrial economic paradigm. Methods: The authors associate the content of economic growth with three principal criteria: innovativeness, sustainability and inclusiveness that attach new quality to the category under investigation. Thereat, neo-industrial economic growth is understood as the manifestation of the expanded reproduction of national economy with no detriment to the environment, when not only the final product is improved (in the system of national accounts it corresponds to Gross Domestic Product (GDP) and national income), but also when the economic potential of the country is enhanced and intensified (production assets, inventories, labor), when well-being of the population is increased (measured by GDP and national income growth rates per capita), and when social inequality is reduced. Findings: The new quality indicators and factors of economic growth have been suggested. The study justifies the conclusion that the export-oriented resource-based model of economic growth hampers the achievement of the identified criteria and does not ensure any efficient and high-quality social and economic development of the country. The suggested economic model proves the abovementioned conclusion and testifies of the fact that the country's dependency on natural resources does not affect economic growth directly, but it does so through the system of governmental institutions. Thereat, in the states where these institutions are deficient, the latter, affected by the availability of natural resources, deteriorate even more, because the people in power try to formalize in legislation their easy access to these resources, thus, in turn, considerably reducing the potential economic growth. Applications/Improvements: The study presents suggestions to create the preconditions for neo-industrial economic development in the Russian Federation.
\end{abstract}

Keywords: Economic Growth, Innovativeness, Inclusiveness, New Industrialization, National Innovation Strategy, National Innovation System, Resource Curse, Sustainability

\section{Introduction}

Today it is difficult to deny the truth that global economy is in a state of permanent crisis, of total, planetary-scale, systemic crisis ${ }^{1}$. This stance is shared by many leading foreign and domestic scientists ${ }^{2-6}$ who performed economic analysis of the nature, reasons and specifics of development of the global financial and economic crisis of 2008 - 2009. Their works justify the conclusion that a systemic mistake has been made in the formation of current mar- ket economy model; this mistake is associated with the uncontrollable growth of the financial component element that lost touch with the real economy and gave birth to systemic crisis, to a new type in the classification of economic crises 5 .

Within the framework of the current model of economic development the reality and rationality of economy, some certain limitedness of consumption, have mutated, and to some extent turned into virtual "chrematistics" and limitlessness of consumer society with all

${ }^{*}$ Author for correspondence 
the negative consequences that follow ${ }^{1}$. Undoubtedly, this situation restrains the movements of social and economic system toward its continuous development and evolution.

At this background the scientific community becomes ever more convinced that there is a necessity or even an inevitable urge to change the economic development paradigm, to establish the new model of functioning national economy that would break free from the abovementioned detrimental effects. However, the model has not been chosen so far, and economic science still continues the fierce disputes as regards the objectives and the principles of its organization opposing, as ever, the well-known "liberal" and Keynesian approaches ${ }^{7,8}$. There at, support is being increasingly rendered to the ideas about the advisability to combine traditional market mechanisms based predominantly on applying the tools of competition with the efficient methods of governmental regulation.

Within the abovementioned discussion ever greater professional and social recognition is gained by neoindustrial paradigm of modern social and economic development set forth by S.S. Gubanov, the editor-in-chief of Russian magazine "The Economist", and comprehensively justified in his program monograph and in a series of his articles ${ }^{9-11}$. New industrialization is characterized by the transition to production process automation, information system development, focus on the environment, formation of the new type of social reproduction: science-driven, high-tech, mass labor saving and environmentally efficient; it represents the new developed stage of the modern type of historical progress $\frac{12,13}{}$.

The new concept associates neo-industrialization with those real changes (actually occurring or expected) in the scope of labor and economic activity that are embodied in such terms as "new economy", "information society", "knowledge economy", etc., which many researchers got used to identify with "postindustrial society" However, there is every reason to maintain that it is exactly the neo-industrial society supported by the accumulated well-developed industrial and technological basis, by highly intelligent human capital and by science as direct productive force that can have in its possession the true "knowledge economy" that can be "politically sovereign, economically efficient, socially just". On the contrary, the concept of "postindustrial society" is trying to "pull out" the material core, to tear it apart from its material basis as from the foundation for its development. Thus, the emphases are shifted leading to similar consequences for the real operational conditions of modern economy.
Given the long-run dialectic interrelation that exists between economic development and economic growth, ${ }^{17}$ it is just to say that the quality of social and economic development does predetermine the efficiency of economic growth and vice versa. The authors of this study believe that from these perspectives new industrialization is a driver of the true (efficient) economic growth and of the new quality of social and economic development of the country.

From the perspectives of neo-industrial paradigm not every GDP growth is good for society. If it is associated with deindustrialization of productive forces, with contamination of the environment, with the interpretation of economic resources in terms of the units of the low quality final products, with inefficient use of the accumulated human potential, etc., then such GDP growth should be considered as a destabilizing factor of economic development $\frac{18}{}$.

Making their contribution to the abovementioned discussion the authors of this study will try to perceive the problem through the prism of neo-industrial content of national economy growth as one of the most important preconditions for social and economic progress of the country.

\section{Concept Headings}

On the whole, the complex social and economic situation in Russia of today was expected, and it was primarily caused by the so-called raw materials export model of development of national economy. Russian scientists already used to expostulate on the necessity for the Russian Federation to choose another vector of development that should have been different from the one chosen by the "reformers"; however, the urgency of the problem was smoothed by active external economic market conditions as regards prices for energy sources, by successful expansion of infrastructural monopolies in the raw materials export market and by the positive dynamics of nominal incomes of Russian citizens $\mathbf{1 9}^{19,20}$.

The shift in scientific and social consciousness occurred under the effects of the global crisis of 2008 - 2009, under the conditions of anti-Russian policy of destructive sanctions initiated by the USA in international markets, under the conditions of the prolonged autonomous recession. As a result of these ordeals, there is, finally, a clear understanding of the fact that the resource-based and monetary GDP growth caused by petrodollar inflation leads to the 
disintegration of the raw materials reproduction and of the technologies in the extracting, mining and reprocessing industries, of both long-term and short-term interests, of monetary and goods proportions, of savings and consumption, of science and production, of property and incomes, etc ${ }^{10,11}$.

Undoubtedly, such kind of growth cannot meet the requirements on national economy, inasmuch as it exacerbates the abovementioned problems instead of solving them. In this context positive GDP dynamics directly shows that the economy is growing without being developed which, finally, predetermines its systemic backwardness.

Under current conditions it is impossible for Russia to come out of the large-scale autonomous recession onto the trajectory of sustainable social and economic development without abandoning the raw material export model of national economy for the benefits of new industrialization aimed at competitive and secure development of the country based on the progressive structural diversification of the economy, on accumulating and employing highly intelligent human capital in most effective manner, the increased efficiency of social labor and improved living standards of the population and social consolidation of the country. It is only neo-industrial economic model that can trigger the fundamental internal drivers, sources and factors of economic growth and development of Russia.

The considerations suggested within the framework of this study are dedicated to justifying the criteria, indicators and factors of neo-industrial economic growth and to evaluating their prospects in Russia.

\section{Literature Review}

It is known that conceptual constructs of every science are founded on a system of categories. This system is not static; when the paradigms change (both general scientific and particular ones), when general scientific theories can no longer explain the emergence of new scientific factors, then the theories and the categorical constructs of science have to change as well. At the same time, the development of new paradigms is not a discretional process; therefore, here the new and the old theories and categories coexist.

Presently, Russian economic school (I. Blagikh, A.V. Buzgalin, S.Yu. Glazyev, R.S. Grinberg, S.S. Gubanov, A.E. Karlik, V.T. Ryazanov, S. Tolkachev, etc.) has been busily formulating the neo-industrial paradigm of the modern stage of historic development that would eliminate the existing contradictions and the limitations of the paradigm of "postindustrial society"14-16.

According to neo-industrial paradigm, the new content is now attached to the definition of "economic growth".

The most fundamental theories of economic growth have been developed in the second half of the $20^{\text {th }}$ century. They can be subdivided into post-Keynesian (H. Singer, R. Prebisch, H. Leibenstein, R. Nurkse, W. Rostow, M. Bruno, H. Carter, etc.), neoclassical (W. Lewis, J. Fei, G. Ranis, E. Heckscher and B. Ohlin), institutional (G. Myrdal, T. Schultz, H. de Soto), radical left (C. Furtado, S. Amin, A. Emmanuel). The analysis of the qualitative changes in economic growth has been carried out by E. Denison $\frac{21-22}{}$, the emphasis has been laid on the qualitative factors within the "new models of growth" (R. Solow, R. Lucas, P. Romer) and on the concept of inclusive economic growth and "green economy" ${ }^{23}$. To understand the essence of the neo-industrial type of economic growth it is also important to clarify its connections with such notions as "development", "sustainability" and "economic security". Thus, as long back as in 1912 in his book "The theory of economic development" J. Schumpeter introduced the division between economic growth and economic development. While the first represents the increased output and consumption of the same products and services in course of time, economic development implies the emergence of something new and unknown, in other words, innovation ${ }^{17}$.

Modern economic science interprets development as one of the components of economic security ${ }^{24,25}$. It should be noted that not every development meets the requirements of security. For instance, the type of development associated with violations of ecological norms, with exacerbated social inequality, with production for production's sake without heeding the meaningful well-being orientations of the population does not meet the abovementioned requirements ${ }^{26}$.

Supported by the theoretical basis above the authors of this study suggest their own definition of economic growth that is adequate to the drivers of neo-industrial economic paradigm, and they interpret it as the manifestation of the expanded reproduction of national economy without any detriment to the environment, when not only the final product is improved (in the system of national 
accounts it corresponds to GDP and national income), but also when the economic potential of the country is enhanced and intensified (production assets, inventories, labor), when the well-being of the population is increased (measured by GDP and national income growth rates per capita), and when social inequality is reduced 27 . With this interpretation its key factors are represented by the factors of efficiency and competitiveness that ensure sustainable social and economic development of the country.

Raw material export model of economic development that has been established in the post-reform Russia cannot ensure efficient utilization and further development of the available economic potential of the country or ensure its transition to the new progressive neo-industrial society that should be politically sovereign, economically efficient and socially just and should possess the true "knowledge economy". This task is being successfully solved in the process of increasing the neo-industrial content of economic growth. Major criteria of this principally new type of economic growth are innovativeness, sustainability and inclusiveness. Such growth is ensured through factors of efficiency and competitiveness.

\section{Method}

\subsection{Holistic Sociological Approach}

which has not gained wide recognition in domestic economic studies yet, but which, nevertheless, proves useful in developing the new paradigm ${ }^{28}$. According to this approach the analysis of economic dynamics should be based on the principles as follows:

- recognition of the viability of social system and the impossibility to consider the processes of economic development detached from the processes occurring in the society;

- identification and investigation of the driving forces of economic transformations;

- variability as an inseparable quality of economic system.

\subsection{Comparing Threshold Values of Economic Security Indicators with their Actual Values}

which is the principal method of general theory of economic security?
It should be noted that threshold value is a tool of economic security; it is a quantitative determination of national interests in the sphere of economy. The threshold values determine the boundaries between dangerous and non-dangerous phenomena in different areas of economy. $\cdot 24$

Comparing real values of economic security indicators with their threshold values it is possible to judge on current danger and potential threats, to quantitatively estimate the urgency of the crisis situation in the sphere of human life under investigation, to form the complex of program and objective-oriented measures to mitigate and eliminate threats taking into account their fixed locations.

\subsection{Building Econometric Model}

That would characterize the dependency of the economic growth in the country on the availability of natural resources and its export capacities. GDP growth per capita was taken as an indicator of economic growth. The methodological foundation of such model was represented by the scientific investigations dedicated to the so-called concept of "resource curse" that in turn developed the results of earlier investigations ${ }^{29-31}$.

\section{Results}

Retrospective analysis and systematization of different theoretical views on economic growth enable its consideration as a central problem of modern society, as a prerequisite for economic development and improvement of the well-being of the population, as a precondition for ensuring the national economic security. Thereat, economic growth is understood not as short-term but as long-term changes in the real production output associated with the development of social productive forces.

The authors of this study believe that under this approach the investigation of neo-industrial content of economic growth implies the justification of the new decision-making criteria and indicators for such type of economic growth; justification of the factors that predetermine economic dynamics, changes in the sector and in reproduction proportions, transformation of institutional structure, etc.

Supported by the definition of neo-industrial type of economic growth formulated in Section 3, the authors think it is appropriate to distinguish its three major cri- 
teria as follows: 1) innovativeness; 2) sustainability, and 3) inclusiveness.

The choice of the abovementioned criteria and their contents within the framework of the drivers of neoindustrial economic paradigm will be explained and described below.

As regards the first criterion of neo-industrial type of economic growth - innovativeness - the following has to be noted.

At the stage of formation of the "knowledge economy" that is intrinsic to neo-industrial society ${ }^{9.11}$, among four factors that predetermine economic growth: labor, natural resources, capital and scientific and technical level the latter is considered by scientific community to be decisive in the long run ${ }^{32}$. There at, the word combination "in the long run" is by no means unimportant. Within the short historic period other factors can be decisive as well (for example the level of institutional development, political stability, law and order, etc.). Turning back to the "long run" an $\operatorname{article}^{33}$ famous in scientific circles has to be remembered as the one that started the investigations of the long trajectories of economic development. According to F.A. Ramsey, the true "knowledge economy" only emerges when knowledge (scientific or obtained otherwise) becomes the independent participant of economic process. Economic realization of knowledge makes innovation.

According to J. Schumpeter, innovation that represents the marketable implementation of a new idea is the motor of economic development $t^{\frac{17}{7}}$. Following Schumpeter's approach a famous Russian innovation system researcher O.G. Golichenko defines innovation as economic implementation of new or considerably improved product (goods and services), process, new marketing or organizational method in business practices, in the arrangement of workplaces or external relations between economic

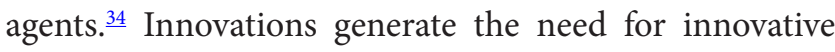
activities that represent the aggregate of all scientific, technological, organizational, financial and commercial steps that lead toward innovation either implicitly or explicitly. Innovative activity covers research and development even in cases when they are not aimed directly at developing some particular innovation ${ }^{\frac{35}{5}}$ but facilitate its invention anyway.

The progress of innovative activities is founded on the complex system of the interrelations between the elements that produce different types of knowledge, manage its flows, distribute and ensure its application and finally result in the efficient employment of highly intelligent human capital.

Recognizing the complexity and the multifaceted nature of innovative activities the authors of this study have developed the methodology to evaluate the dynamics and intensity of innovative processes in regional economy ${ }^{27}$. Its methodological basis is represented by European methods applied for calculating Global Competitiveness Index (GCI); by index of innovations in knowledge-based societies (EIS), by general sustainable development index; by innovation system macro-model developed by D.N. Chen and C.J. Dahlman consisting of four functional blocks of indicators (economic, scientificinnovative, information, educational). Besides, the works belonging to Russian scientists $\frac{25,26}{}$ and dedicated to RF economic security monitoring and indicator systems have been used. The authenticity and comparability of the obtained results can be verified by the data from official statistical sources.

Given the above, it was suggested that the efficiency of the current innovative processes in a subject of the federation should be estimated through the generalized index of knowledge economy in the region $\left(\mathrm{Y}_{\mathrm{i}}\right)$. It should be calculated as an arithmetic mean of the indices of such functional blocks of indicators as financial-economic, scientific-technical, educational and information-communicational $\left(\mathrm{x}_{\mathrm{j}} \mathrm{j}=1, \ldots, 4\right)$ :

$Y_{i}=\frac{\sum_{j=1}^{N} x_{j}}{N}$.

The critical level of the index is determined by value of 0.5 . The more the regional value of the index (indicator) exceeds the critical level, the more efficiently develop the innovative processes in the region.

The authors of this study have undertaken the analysis of the intensity of innovation process development in the specific subject of the Russian Federation, in the Republic of Mordovia. The calculations showed that the values of knowledge economy index in the region over the whole period of investigation remained lower than the critical level of the index, and over 2014 they decreased to 0.322 as compared to 0.329 in 2013. This fact testifies of the insufficient intensity of the innovative processes in the economy of the region, of low efficiency of its innovation system stipulated, among other factors, by the destructive factors of Russian economy in general and by the standing disproportions that formed due to the raw material export model of economic development of the country. 
Thus, over the last decades Russia has been ever more seriously lagging behind the developed countries in terms of the "knowledge economy" index. Today the share of knowledge economy that primarily includes education, research and development, information and biotechnologies, healthcare in GDP of the Russian Federation makes no more than $15 \%$ (for reference: in the countries of "the Group of Seven" it accounts for $35 \%) . \underline{36}$ Healthcare sector lags behind considerably; total expenses for this sector, private and shadow expenses including, do not exceed $5 \%$ of GDP versus $10 \%$ in the countries of Western Europe. According to The World Bank, expenses for education in Russia amount to $4.1 \%$ of GDP. In terms of this indicator the Russian Federation occupies position 98 out of 153 and is very close to Paraguay, Tajikistan and Bhutan. Fundamental science received USD 1.8 billion from the state budget in 2014 (for reference: annual budget of Harvard University (USA) amounts to over USD 7 billion. Expenses for civil science as percentage of GDP in Russia compared to similar figures in other countries are shown in Figure $1 \frac{36}{}$.

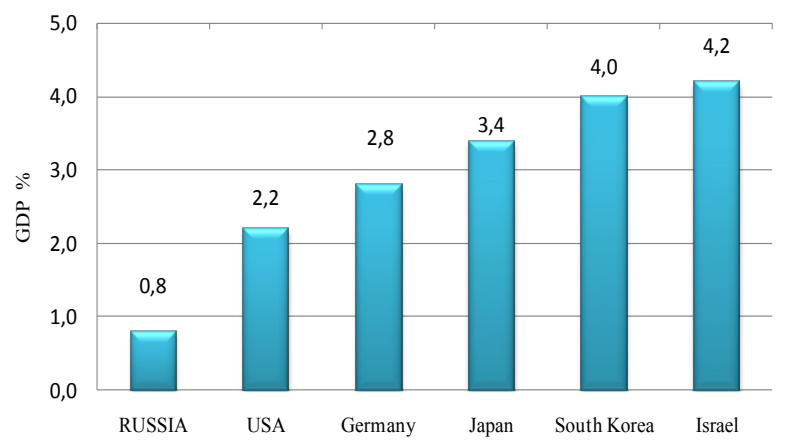

Figure 1. Expenses for civil scientific research.

Undoubtedly, current situation in "knowledge economy" in Russia does not help overcome deindustrialization of productive forces and the phenomenon of the contracted reproduction; it also hampers efficient utilization of the accumulated human potential ${ }^{37}$.

The Table 1 shows the comparison of some indicators of scientific and technical security in the Russian Federation with their threshold values.

The analysis of the dynamics of the indicators shown in Table 1 demonstrates the threats associated with backwardness in the sphere of innovations. The data in Figure 2 show that the most serious concerns are caused by the indicators as follows: "Expenses for civil science" and closely related indicator "Share of innovative products in total amount of delivered industrial products". And such indicator as "Share of exported machines, equipment and transport vehicles, chemical industry products in total amount of export" demonstrate the raw material export orientation of the country.

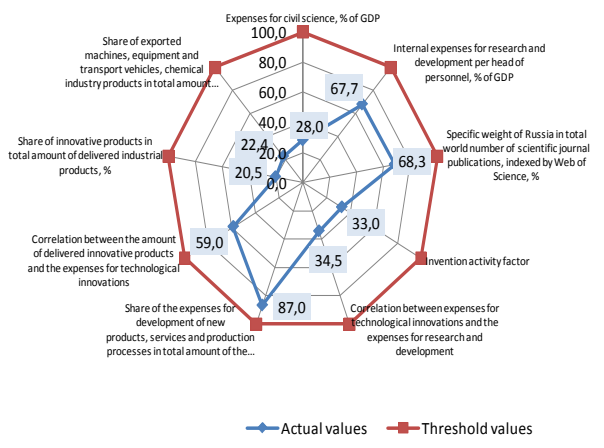

Figure 2. Comparing the indicators of scientific and technical sphere in Russia with their threshold values (2014).

The results of the investigation above testify of the necessity for the state authorities to take urgent measures to improve the situation.

From the perspectives of neo-industrial economic paradigm sustainability of economic growth is inextricably connected with the efficient resource utilization and saving in the first place ${ }^{26}$. This understanding of sustainability is founded on the well-known rule of J. Hartwick, according to which sustainable development can be ensured by investing the whole rent obtained from natural resources that are determined as the difference between the market price of the resource and the marginal costs for its mining into the reproduction capital, into education and environmental protection ${ }^{31}$. According to this rule, scientists suggest that weak and strong sustainability should be distinguished ${ }^{41}$. The former means preservation of the value of the aggregate stock of capital (material, human, natural) and the exchangeability of its types. Strong sustainability implies that each type of capital should be preserved at the level that is not lower than some certain minimal level.

Neo-industrial paradigm actualizes the concept of strong sustainability. And this is for a good reason. It should be remembered that since the 1970s due to the extensive economic and demographic growth there started the 
Table 1. Dynamics of indicators of scientific and technical security in the Russian federation over $2010-2015$ compared with their threshold values

\begin{tabular}{|c|c|c|c|c|c|c|}
\hline \multirow[t]{2}{*}{ Indicator } & \multirow{2}{*}{$\begin{array}{l}\text { Indicator } \\
\text { threshold } \\
\text { value }\end{array}$} & \multicolumn{5}{|c|}{$\begin{array}{l}\text { Actual } \\
\text { threshold value }\end{array}$} \\
\hline & & 2010 & 2011 & 2012 & 2013 & 2014 \\
\hline Expenses for civil science, \% of GDP & 2.00 & 0.51 & 0.53 & 0.53 & 0.60 & 0.56 \\
\hline $\begin{array}{l}\text { Internal expenses for research and development per head of } \\
\text { personnel, \% of GDP }\end{array}$ & 1.61 & 1.13 & 1.02 & 1.05 & 1.06 & 1.09 \\
\hline $\begin{array}{l}\text { Specific weight of Russia in total world number of scientific } \\
\text { journal publications, indexed by Web of Science, } \%\end{array}$ & 3.00 & 1.95 & 1.91 & 1.81 & 1.82 & 2.05 \\
\hline $\begin{array}{l}\text { Invention activity factor, the number of domestic patent } \\
\text { applications for inventions submitted in Russia per } 1000 \text { people } \\
\text { of the population }\end{array}$ & 5.00 & 2.01 & 1.85 & 2.00 & 2.00 & 1.65 \\
\hline $\begin{array}{l}\text { Correlation between expenses for technological innovations and } \\
\text { the expenses for research and development }\end{array}$ & 2.00 & 1.31 & 0.83 & 0.77 & 0.67 & 0.69 \\
\hline $\begin{array}{l}\text { Share of the expenses for development of new products, services } \\
\text { and production processes in total amount of the expenses for } \\
\text { technological innovations, } \%\end{array}$ & 50.0 & 21.0 & 24.0 & 36.0 & 37.0 & 43.5 \\
\hline $\begin{array}{l}\text { Correlation between the amount of delivered innovative } \\
\text { products and the expenses for technological innovations }\end{array}$ & 5.00 & 3.10 & 2.87 & 3.18 & 3.15 & 2.95 \\
\hline $\begin{array}{l}\text { Share of innovative products in total amount of delivered } \\
\text { industrial products, } \%\end{array}$ & 40.00 & 4.90 & 6.10 & 7.80 & 8.90 & 8.20 \\
\hline $\begin{array}{l}\text { Share of exported machines, equipment and transport vehicles, } \\
\text { chemical industry products in total amount of export, \% }\end{array}$ & 50.0 & 11.6 & 11.3 & 11.2 & 11.3 & 11.2 \\
\hline
\end{tabular}

epoch of "overconsumption of natural resources", when the needs of man exceeded the capacities of the planet. If in 1999 the value of this overrun amounted to $20 \%$, then now the mankind consumes on average 1.5 times more than the nature is capable of producing in a year. This trend of the world economy has become to be named "ecological debt" $\underline{23}$.

The calculations performed by scientists over recent years showed that if the level of per capita consumption in the countries of BRICS (Brazil, Russia, India, China and South Africa) becomes equal to American level, then, in order to meet this demand, natural resources of 5 such planets as the Earth should be required ${ }^{42}$.

The observed contradiction between the need to satisfy the growing demand and the economic overload on natural complexes is associated with the deterioration of biosphere affected by activities of $\operatorname{man}^{43}$. Thereat, the fastest growing component of "ecological debt" of the mankind is represented by atmospheric emissions of carbon dioxide $\left(\mathrm{CO}_{2}\right)$ accompanied by air temperature increase and greenhouse effect. Today they account for $60 \%$ of the total demand of the mankind for renewable biological resources that are conventionally called "ecological footprint" $\underline{23}$.

Figure 3 illustrates the positions of different countries depending on the specific indicators of accumulation and consumption of capital stock in 2013 and the amounts of greenhouse gas emissions.

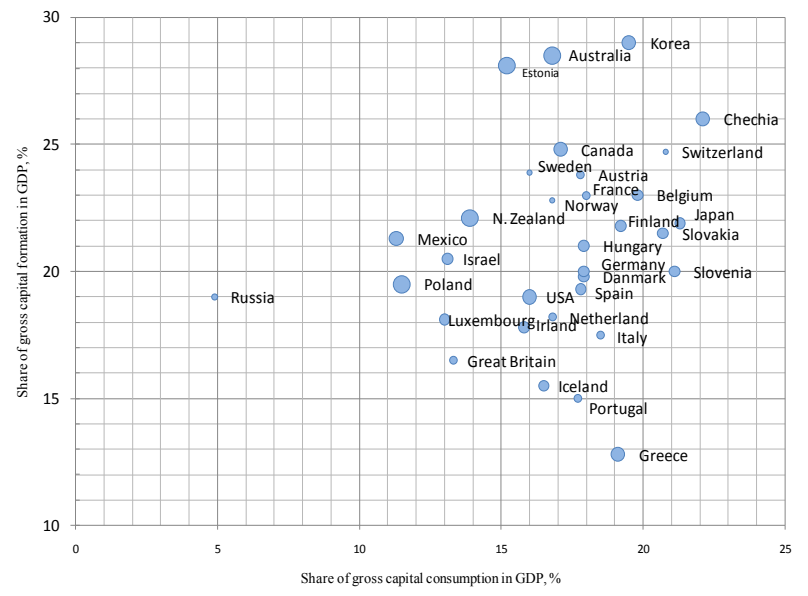

Figure 3. "Ecological footprint" in 2013 in different countries. 
In Russia the share of "ecological footprint" of carbon component amounts to $68 \%{ }^{44}$. In this regard, according to the experts, the country should stop providing subsidies for hydrocarbon extraction and use the available funds for developing "green generation" $\underline{45,46}$.

The problem of wastes should also be considered within the framework of "ecological footprint". Neoindustrialization means new materials and new types of wastes. According to different estimations, the amount of the accumulated wastes in the Russian Federation makes 90 to 120 billion tones and the damage to the environment caused by these accumulated wastes amounts to $4.6 \%$ of GDP. Moreover, Russia is considerably lagging behind the EU countries in terms of the amount of reprocessed wastes. If in European countries over $32 \%$ of wastes are reprocessed, and in the USA this figure amounts to $23 \%$, then in Russia it makes just $4.5 \%$ 흐․

From the perspective of neo-industrial paradigm, in order to achieve sustainable development of the economy people should not struggle against wastes (as they do now) but rather they should redirect their flows into economic circulation and to create a closed cycle of resources.

With respect to the above an important way to repay "ecological debt" and a precondition for ensuring sustainable economic growth are represented by focusing the process of reproduction on the environment. Ecological reproduction is interpreted by the authors of this study as a continuous movement and as restoration of the conditions for satisfying material, spiritual and esthetic needs of man and society in the system of the interrelations "society - environment" based on introducing into the production processes the new ways to apply the opportunities and the forces of nature, based on investing in ecological industry and based on the intensive development of businesses to reprocess the wastes of production and consumption, i.e. recycling. In this context environmental focus is interpreted not only from the perspectives of economic (cost) estimation, but also from the perspectives of moral and ethical principles. To repay "ecological debt" means not only to preserve ecological balance and restore the disturbed natural objects, but also to "make amends" to nature for human mistakes.

According to the experts, to support nature's ability for self-reproduction and to preserve the natural quality of the environment, the expenses for environmental protection should amount to no less than $5 \%$ of GDP ${ }^{26}$. Actual expenses for environmental protection in most countries are much lower (including Russia).
To evaluate the degree of ecological well-being of a territory, several widely applied indicators can be used: Environmental Sustainability Index (developed by Yale and Columbia University); "ecological footprint" indicator (World Wildlife Fund); economic block indicators in the system of sustainable development indicators (recommended by the United Nations Commission on Sustainable Development) etc.

In the context of neo-industrial economic paradigm mobilization of social resources and employment of social potential also play the important role in ensuring strong sustainability of economic growth. This is about the establishment of new terms in the notions and categorical constructs of scientists and practitioners that would testify of the gradual recognition of the ever increasing significance of social subsystem as a relatively independent factor of neo-industrial development ${ }^{47}$.

Thereat, the notion of "social resource" when referred to the economic system is used as a characteristic of some stock (reserve) of non-material driving forces of development that are positioned on the quality side of established social relations and social institutions that not only could become the factors of acceleration but that could as well hamper the development.

In economic literature social potential is interpreted as the population of some certain society (territory) as bearers of demographic, labor, educational and intellectual potentials and of the potential of culture ${ }^{47}$. From the perspectives of social potential reproduction its key component element is represented by its demographic potential that predetermines biological reproduction of the population.

At the same time, the reproduction of social capital includes socialization as well. i.e. the reproduction of labor resources, professional and qualification structure of economically active population, etc. This fact stipulates the necessity to distinguish within the structure of social potential one of its most important element represented by juvenile potential as an aggregate of demographic, labor, educational, intellectual potential and potential of culture of that part of the population that is represented by younger generation. To estimate the value and the quality of juvenile potential, existing indicators of social statistics can be used.

In order to create the progressive neo-industrial society that would be not only politically sovereign and economically efficient, but socially just as well; the society, for whom the reproduction of man and the standards of 
life are of paramount importance ${ }^{9}$, the inclusive economic growth should be most principal, i.e. the growth that positively affects the well-being of as wide circles of the population as possible and that helps equalize the opportunities of all strata of society ${ }^{\underline{48}}$.

The undertaken study enables the conclusion that today the major problem of the $21^{\text {st }}$ century that hampers social and economic development is justly recognized to be represented by economic inequality ${ }^{49-51}$ Focus on the consumption and its growth stipulated by postindustrial economic paradigm generates social stratification of society. In many countries growing superfluous social inequality is observed. The gaps between the national wealth of the developed and the developing countries are increasing.

In his famous book called "Capital in the $21^{\text {st }}$ century" T. Piketti distinguishes two major reasons that make for stratification of society: "a society of petits rentiers" and "a society of superstars" (or perhaps "supermanagers,"). The scientist notes: "The share of the property belonging to the upper one thousandth of the wealthiest people on the planet now amounts to circa $20 \%$ of total property, the share of the upper centile makes circa $50 \%$, and the share of the upper decile is in the range of 80 to $90 \%$; the poorest half of the world population possesses less than $5 \%$ of total property" ${ }^{\prime 9}$. It is clear that within the framework of political and economic institutions of today this dynamics can hardly be opposed ${ }^{49}$. The data in Table 2 show that similar situation is observed in Russia.

There is no doubt that such situation does not stimulate growth of labor efficiency or labor motivation of the overwhelming majority of the population; it generates legal and labor nihilism in society. Thus, the above stipulates the need for new, neo-industrial economic paradigm abandoning the raw material export model of national economy in Russia.

Summarizing all the above the conclusion can be made that the positive GDP growth rates observed in Russia in the 2000s cannot be justly recognized as true economic growth. This growth did not meet the requirements of the decision-making criteria described above: innovativeness, sustainability and inclusiveness, and it were associated with the narrowed down reproduction of the economy and social sphere ${ }^{37}$. Caused predominantly by favorable economic situation in the external markets depending on the oil prices, GDP growth in the Russian Federation, although it has created the new situation in the sphere of currency and monetary potential, proved to be extremely unsustainable. Russian economy was engulfed by the global financial and economic crisis that even more obviously demonstrated its low efficiency and technological backwardness as compared to the developed countries; and then Russia found itself in the conditions of autonomous recession Figure 4.

Table 3 shows comparative analysis of actual GDP growth rates and the quality growth index in Russia over 1996-2014.

The principal conclusion is as follows: GDP growth in Russia was of monetary and raw material nature and was associated with pushing out the non-resource sectors of the economy that should in the long run become the drivers of economic growth based on the improved effi-

Table 2. Distribution of total amount of cash incomes of the population in the Russian federation in 1980 2014

\begin{tabular}{|c|c|c|c|c|c|c|c|c|c|}
\hline \multirow[t]{2}{*}{ Indicator } & \multicolumn{9}{|l|}{ Years } \\
\hline & 1980 & 1990 & 1995 & 2000 & 2005 & 2010 & 2011 & 2013 & 2014 \\
\hline $\begin{array}{l}\text { Cash income: total, } \% \\
\text { including by } 20 \% \text { groups of population: }\end{array}$ & 100 & 100 & 100 & 100 & 100 & 100 & 100 & 100 & 100 \\
\hline first (with minimal income) & 10.1 & 9.8 & 6.1 & 5.9 & 5.4 & 5.2 & 5.2 & 5.2 & 5.2 \\
\hline Second & 14.8 & 14.9 & 10.8 & 10.4 & 10.1 & 9.8 & 9.8 & 9.8 & 9.9 \\
\hline Third & 18.6 & 18.8 & 15.2 & 15.1 & 15.1 & 14.8 & 14.9 & 14.9 & 14.9 \\
\hline Fourth & 23.1 & 23.8 & 21.6 & 21.9 & 22.7 & 22.5 & 22.6 & 22.5 & 22.6 \\
\hline Fifth (with maximal income) & 33.4 & 32.7 & 46.3 & 46.7 & 46.7 & 47.7 & 47.4 & 47.6 & 47.4 \\
\hline $\begin{array}{l}\mathrm{R} / \mathrm{P} \text { ratio (ratio of income } \\
\text { differentiation), times }\end{array}$ & - & - & 13.5 & 13.9 & 15.2 & 16.6 & 16.2 & 16.3 & 16.0 \\
\hline $\begin{array}{l}\text { Gini ratio (income concentration } \\
\text { index) }\end{array}$ & - & - & 0.387 & 0.395 & 0.409 & 0.421 & 0.417 & 0.419 & 0.416 \\
\hline
\end{tabular}


Table 3. Comparative analysis of real GDP growth rates and economy growth quality index in the Russian federation in $1996-2015$

\begin{tabular}{|l|l|l|l|l|}
\hline Years & $\begin{array}{l}\text { GDP growth index (at market } \\
\text { prices), \% of the previous year }\end{array}$ & $\begin{array}{l}\text { GDP deflator, \% of the } \\
\text { previous year }\end{array}$ & $\begin{array}{l}\text { Economy growth } \\
\text { quality index }\end{array}$ & $\begin{array}{l}\text { Human development } \\
\text { index }\end{array}$ \\
\hline 1996 & 96.4 & 145.8 & -11.69 & N/A \\
\hline 1997 & 101.4 & 115.1 & -9.79 & 0.747 \\
\hline 1998 & 94.7 & 118.6 & -4.51 & 0.771 \\
\hline 1999 & 106.4 & 172.3 & -10.33 & 0.775 \\
\hline 2000 & 110.0 & 137.6 & -2.76 & 0.776 \\
\hline 2001 & 105.1 & 116.5 & -2.24 & 0.779 \\
\hline 2002 & 104.7 & 115.5 & -2.30 & 0.795 \\
\hline 2003 & 107.3 & 114.0 & -0.92 & 0.795 \\
\hline 2004 & 107.2 & 120.1 & -1.79 & 0.779 \\
\hline 2005 & 106.4 & 119.2 & -2.00 & 0.795 \\
\hline 2006 & 107.4 & 115.8 & -1.14 & 0.753 \\
\hline 2007 & 108.1 & 113.5 & -0.67 & 0.797 \\
\hline 2008 & 105.2 & 118.0 & -0.12 & 0.817 \\
\hline 2009 & 92.2 & 102.0 & -0.11 & 0.782 \\
\hline 2010 & 104.5 & 114.2 & -0.09 & 0.817 \\
\hline 2011 & 104.3 & 115.9 & -0.11 & 0.782 \\
\hline 2012 & 103.5 & 108.3 & -0.05 & 0.775 \\
\hline 2013 & 101.3 & 104.8 & -0.03 & 0.784 \\
\hline 2014 & 100.7 & 107.2 & -0.06 & 0.788 \\
\hline 2015 & 96.3 & 107.7 & -0.12 & 0.798 \\
\hline
\end{tabular}

Table 4. Variables used in the econometric model and their description

\begin{tabular}{|l|l|l|}
\hline $\begin{array}{l}\text { Name of variable } \\
\text { and notations }\end{array}$ & Variable description & Information source \\
\hline Minxp & $\begin{array}{l}\text { Average share of annual export of mineral resources in } \\
\text { RF GDP over 1992 - 2014 }\end{array}$ & GDP data of The World Bank \\
\hline Latitude & $\begin{array}{l}\text { Absolute value of geographical latitude of the country, } \\
\text { takes values form 0 to 1 }\end{array}$ & La Porta et al \\
\hline Tariff & $\begin{array}{l}\text { Average tariff rate for imported goods over 1992 - } \\
2014\end{array}$ & World Integrated Trade Solution System \\
\hline Isubsoil & $\begin{array}{l}\text { Logarithm of proved mineral resources in RF in 2000, } \\
\text { USD per capita }\end{array}$ & The World Bank \\
\hline Goveffect & $\begin{array}{l}\text { The indicator reflects the quality of governmental } \\
\text { services and the degree of independence on political } \\
\text { pressure. Measures from -2.5 (weak) to +2.5 (strong) }\end{array}$ & World Governance Indicators \\
\hline Lgdp91 & Logarithm of GDP per capita in 1991 & The World Bank \\
\hline Presid & $\begin{array}{l}\text { Binary variable: } 1 \text { (presidential regime); } \\
0 \text { (parliamentary regime) }\end{array}$ & The World Bank \\
\hline Plur00dp & $\begin{array}{l}\text { Binary variable: } 1 \text { if the parliament is elected } \\
\text { according to the rule of relative majority; 0 - under the } \\
\text { conditions of proportional rule }\end{array}$ & $\begin{array}{l}\text { Kunicova J. and S. Rose-Ackerman. Electoral } \\
\text { Cules and Constitutional Structures as } \\
\text { Political Science. 2005, 35, } 573 \text { - 606. }\end{array}$ \\
\hline G9214 & $\begin{array}{l}\text { Average GDP growth per capita in RF over 1992 - } \\
\text { 2014 }\end{array}$ & Statistical Yearbook of Russia \\
\hline
\end{tabular}


ciency of labor. With this type of growth it becomes very difficult to use the accumulated human capital in efficient manner. This conclusion is confirmed by the built econometric model described in Section 5 of the study.

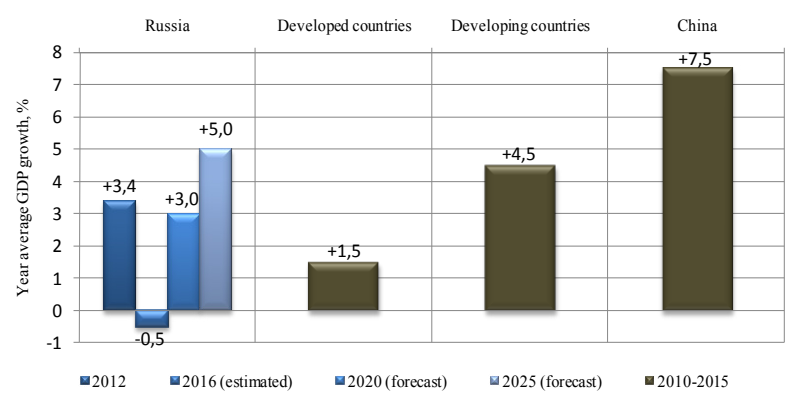

Figure 4. GDP growth year average in different countries of the world.

The authors of this study have undertaken the attempt to analyze the effects produced by the available natural resources of the country and by its export capabilities on economic growth. The results of this investigation are presented in Table 4. In all regressions the logarithm of economic growth was used as control variable.

It should be noted that irrespective of the method of the investigation, the export of natural resources affects GDP growth just negligibly. Regressions (2) and (3) are built applying the method of 2 Ordinary Least Squares (OLS); thereat, in regression (2) the endogenous variable is represented by export of mineral resources (minxp), instrumented on isubsoil; presid; plur00dp;goveffect, and in regression (3) it is represented by the quality of the institutions (goveffect), instrumented on isubsoil and latitude.

The obtained results enable the conclusion that among the selected factors the strongest effects on economic growth are produced by the efficiency of governmental authorities (this variable possesses the highest coefficient). Besides, the obtained regressions confirm the fact that initially available natural resources in the country also produce positive effects on GDP growth (Table 5).

Thus, the developed model proves the theoretical assumptions that dependency of the country on its natural resources affects economic growth not directly but through the system of governmental institutions..$^{30}$ In a state where these institutions are weak the latter, affected by the available stocks of natural resources, deteriorate, because the people in power try to facilitate their access to the resources on legislative level. It is exactly this process (that leads, according to T. Piketti, to the formation of society of "superstars" and "supemanagers") that reduces the potential of growth.

\section{Discussion}

When applied to the modern Russian reality further inert "expectations" of improvements in social and economic situation in the country will lead to stronger negative trends and processes. To change the situation drasti-

Table 5. Regression analysis of the dependency of economic growth in the Russian federation on export of natural resources

\begin{tabular}{|l|l|l|l|}
\hline \multirow{2}{*}{ Variables } & \multicolumn{4}{l|}{ Obtained regressions } \\
\cline { 2 - 4 } & $(1)$ & $(2)$ & $(3)$ \\
\hline Const & $4.491^{* * *}(0.887)$ & $8.290^{* * *}(1.720)$ & $16.826^{* * *}(6.038)$ \\
\hline Minxp & $-1.801(1.330)$ & $4.206(6.107)$ & $0.310(3.609)$ \\
\hline Isubsoil & - & $0.015(0.099)$ & $0.139^{*}(0.079)$ \\
\hline Lgdp91 & $-0.261^{* *}(0.107)$ & $-0.863^{* * *}(0.230)$ & $-2.101^{* *}(0.860)$ \\
\hline Goveffect & - & $1.047^{* * *}(0.376)$ & $3.055(1.568)$ \\
\hline Endogenous variable & & Minxp & Goveffect \\
\hline Number of observations & 87 & 57 & 72 \\
\hline F-statistic & $4.19^{* *}$ & $3.95^{* * *}$ & $4.31^{* * *}$ \\
\hline R2 & 0.09 & 0.12 & 0.02 \\
\hline
\end{tabular}

Note: The dependent variable for all regressions is g9214. Regression (1) - Ordinary Least Squares; regressions (2) - (3) - 2 OLS. Standard errors are given in brackets. Marked with ${ }^{*},{ }^{* *},{ }^{* *}$ are statistically significant values at 10-, 5-, $1 \%$ levels respectively. 
cally and to bring the production process on the way of expanded reproduction, it is necessary to abandon the raw material export model of national economy and to ensure gradual increase of neo-industrial content in the growth of the latter. The authors of this study believe that the solution of this complex task should imply things as follows:

\subsection{Active Industrial Policy}

Active industrial policy that should be focused on rehabilitation of the reproductive independence of national economy based on its deep transformation and technological upgrade. Industrial policy of Russia should be complex and should envisage the formation of the incentives for the transition to neo-industrial model of economy, for changing sectoral and territorial structure of industry, for investments in the high added value production facilities.

Active industrial policy as a matter of priority should include the measures as follows:

- ranking the priorities of science-driven production lines and technologies taking into account the fact that simultaneous restoration and development of their whole range is neither economically possible nor rational;

- developing small innovative enterprises in industrial sector;

- enhancing and developing innovation clusters;

- employing economic mechanisms to stimulate innovations in production.

\subsection{Transformation of the Investment Policy to Solve Two Issues:}

1) Using internal savings of the country for purposes of development; 2) ensuring growth of technical and technological levels of production. Their implementation implies the following:

- rehabilitation of the active part of the capital stock and undertaking research and development in breakthrough technologies in different industries;

- stimulating the upgrades of innovative infrastructure in the economy;

- creating the conditions for growth of investments in the upgrades of capital assets and in techno- logical modernization by means of improving amortization policy;

- facilitating investment activities of the population by creating the conditions for developing "business angels", etc.

\subsection{Reducing the Superfluous Reproductive Dependency of Russian Economy}

Reducing the superfluous reproductive dependency of Russian economy on the situation and trends in the world market by shifting its major focus on the internal market and domestic demand based on the implementation of the import substitution policy. In this regard the following should be envisaged:

- transition to modern international product quality standards; meeting the requirements of these standards can make entrepreneurs intensify innovative activities;

- governmental support to prioritized areas of scientific and technological progress, including fundamental science, investigations in the sphere of healthcare, education, personnel management, life standards of the population, and also in the areas where the Russian Federation occupies competitive positions in the world market (nanotechnologies, development of new energy sources and energy saving, development of new materials, environmental protection and security).

\subsection{Establishment of New "Middle Class"}

Establishment of new "middle class", the class of professionals, where the major criteria for identification should be represented not by the factors of property or income but by the functions performed in the process of reproduction, by the contribution to economic growth and to new model of development, etc.

\section{Conclusion}

In conclusion, we consider it necessary to note that even today Russia has a number of preconditions for neo-industrial breakthrough of the country toward the frontlines of progress. This is all about the innovation potential of defense industrial complex, about the 
competitive positions in nuclear reactor engineering, in designing supercomputers and the relevant networks, about positive moves in the area of microelectronics and nanotechnologies. This is very important, because there should be proper foundations to start the new industrialization.

Hopefully, for the sake of the transition to neoindustrial model of growth of national economy the raw material export model of social and economic development of the country will finally be abandoned; the state would take urgent measures aimed at rehabilitation and development of scientific, technical and intellectual potentials, at efficient employment of the accumulated human capital supported by the internal sources of development, at stimulating science-driven businesses, at expanding the high-tech export.

\section{Acknowledgements}

The study has been developed with financial support from Russian Humanitarian Science Foundation (RHSF), Project No.16-02-00394 "Development of theory and methodology of investigation of recycling as special factor of economic growth in neo-industrial economy".

\section{References}

1. Alpidovskaya M. On new economic model through the prism of highly efficient labor. The Economist. 2015; 10:7882.

2. Krugman P. The return of depression economics and the crisis of 2008. W.W. Norton \& Company, New York; 2009 Sep. p. 224.

3. Krugman P. The return of great depression? world crisis as viewed by Nobel prize winner. Moscow: EKSMO; 2009. p. 336. Available from: http://www.twirpx.com/file/1469286/

4. Soros G. The truth about the financial crisis 2012 [Internet]. 2016 [cited 2016 Nov 10]. Available from: http://www.1pixel. $\mathrm{ru}$ /soroskriz.php.

5. Aksenov VS, Gelvanovskiy MI, Nesterenko YuN, Nikolayev AV, Pogudayeva MYu. World financial crisis and economic security of Russia: analysis, problems and prospects. Moscow: Ekonomika; 2010. p. 205. Available from: http:// www.prometeus.nsc.ru/acquisitions/11-03-29/cont24.ssi

6. Glaziyev SY. Opportunities and restrictions of technological and economic development of Russia under the conditions of structural changes of the world economy: scientific report. Moscow: GOUVPO “GUU”. 2008. Available from: http://spkurdyumov.ru/economy/vozmozhnosti-iogranicheniya-texniko-ekonomicheskogo-razvitiya/

7. Manevich VE. Keynesian theory and Russian economy. Moscow: KomKniga. 2010. Available from: http://www.iprras.ru/articles/manev08-3.htm

8. Dzarasov S. Wither Keynes calls Russia? Moscow: Algorithm; 2012. p. 304. Available from: http://dzarasov.ru/ dzarasov-ss-kuda-keyns-zovet-rossiyu

9. Gubanov S. State breakthrough. Neo-industrialization of Russia and vertical integration. Moscow: Knizhniy Mir; 2012.

10. Gubanov S. Neo-industrialization development model and its systemic algorithm. Economic and Social Problems: Facts, Trends, Forecast. 2014; 33(3):23-44.

11. Gubanov S. On economic model and long-term strategy of new industrialization in Russia. The Economist. 2016; $2: 3-10$

12. Kulkov V. On positioning of new industrialization. The Economist. 2014; 10:49-53.

13. Tolkachev S. One more step, American, toward real evaluation of processing industry's contribution. The Economist. 2016; 4:20-3.

14. Bell D. Future postindustrial society. Experience of social forecasting. Moscow: Akademia. 1999. Available from: http://sov.opredelim.com/docs/89900/index-8997-1.html

15. Toffler E. Third wave: monograph: translated from English. Moscow: AST. 2004. Available from: www.archipelag.ru/ download/book/text_pdf/hantington_wave.pdf

16. Masuda E. Information society as postindustrial society. Moscow: Progress; 1997.

17. Schumpeter JA. The theory of economic development. Capitalism, socialism and democracy: translated from German. Moscow: EKSMO; 2007. p. 864. Available from: http://ecsocman.hse.ru/text/19209076/

18. Shafronov A. Economic growth and production efficiency. The Economist. 2015; 7:80-7.

19. Blagikh I. The country is in need of new industrialization. The Economist. 2014; 10:10-17.

20. Plyshevskiy B. Market reforms and development of the economy of Russia. The Economist. 2014; 9:3-24.

21. Denison E. Investigating the differences in economic growth. Moscow: Progress; 1971. Available from: http:// www.twirpx.com/file/1837565/

22. Denison E. Trends in American economic growth, 192982. Washington, D.C.: The Brookings Institution; 1985.

23. Fueks R. Green revolution: Economic growth with no detriment to environment: translated from German. Moscow: Alpina non-fiction; 2016. Available from: http://www.ecoculture.ru/ecolibrary/green_revolution.php 
24. Senchagov VK editor. Economic security of Russia: general course. Textbook. Moscow: Binom. Laboratory of knowledge; 2015.

25. Senchagov VK. Economic security of Russia. General course: Textbook. $5^{\text {th }}$ Edition (electronic). Moscow, Binom. Laboratory of knowledge; 2015.

26. Senchagov VK. Innovative transformations as an imperative of sustainable development and economic security of Russia. Moscow: Ankil; 2013.

27. Kormishkina LA, Kormishkin ED, Koloskov DA. Economic Growth in Modern Russia: Problems and Prospects in the Context of Neo-Industrial Paradigm. Journal of Applied Economic Sciences. 2016; 6(44):1115-29.

28. Muslyayeva IN. Theoretical foundations of the new paradigm of economic science. In book: Economic theory at the threshold of the $21^{\text {st }}$ century - 2. Moscow: Yurist; 1998. p. 201-5.

29. Sachs J, Warner A. Natural resource abundance and economic growth. BER working paper; 1997. p. 53-98.

30. Sachs J, Warner A. The curse of natural resource. European Economic Review. 2001; 45:827-838.

31. Hartwick J. Intergenerational equity and the investing of rents from exhaustible resources. American Economic Review. 1977; 67(5):972-4.

32. Milner BZ. Innovative development: economy, intellectual resources, knowledge management. Moscow: NITs INFRA-M; 2011.

33. Ramsey FP. A Mathematical Theory of Saving. Economic Journal. 1928; 38:543-59.

34. Golichenko OG. Basic factors of development of national innovative system: lessons for Russia. Moscow: Nauka; 2011.

35. Organisation for Economic Co-operation and Development (OECD). Innovation policy and performance. A crosscountry comparison. OECD, Paris; 2005.

36. Aganbegyan A. Economy will be "pulled off" by science and education. The weekly "Arguments and Facts" number 28. Capital brain [Internet]. 2016 [cited 2016 Nov 10]. Available from: http://www.aif.ru/gazeta/number/32330.

37. Kormishkina LA, Kormishkin ED, Koloskov DA. Multiplier and accelerator effects of investments in the Russian economy (facts, trends and prospects). Indian Journal of Science and Technology. 2016; 9(29):115-28. DOI: 10.17485/ ijst/2016/v9i29/99443.

38. Russia in figures: Statistical handbook. Moscow: Rosstat; 2015.

39. Statistical yearbook of Russia: Statistical pocketbook. Moscow: Rosstat; 2015.

40. UN development program: human development index in countries of the world in 2014 [Internet]. 2016 [cited 2016 Nov 10]. Available from: http://gtmarket.ru/ news/2014/07/24/6843

41. Barskiy VG, Perelet VA. Diagnostics and semiotics of sustainable development. Electronic Scientific Journal Biosphere [Internet]. 2016 [cited 2016 Mar 8]. Available from: http://www.biosphere21century.ru/.

42. Malinetskiy GG. To make dreams come true... High-tech is the way of Russia to future. Moscow: Librokom; 2013.

43. Vernadskiy V. Scientific thought as planter phenomenon. Moscow: Nauka; 1991. Available from: http://www.vernadsky.ru/vernadsky/electronic-library/.

44. Krylatykh EN. Agrarian Europe in the $21^{\text {st }}$ century. Moscow: Letniy Sad; 2015.

45. National accounts of Russia in 2007-2014. Statistical handbook. Moscow: Rosstat; 2015.

46. Organisation for Economic Co-operation and Development (OECD). Investment (GFCF) (indicator). OECD, Paris; 2016. DOI: $10.1787 /$ b679367.

47. Maslova I. Social potential of economic development. Bulletin of the Institute of Economics of the Russian Academy of Sciences. 2008; 2:37-73.

48. Ranieri R, Ramos RA. After all, what is inclusive growth? International Policy Centre for Inclusive Growth (IPC-IG). Originally published as IPC-IG's One Pager; 2013. p. 188.

49. Piketti T. Capital in the $21^{\text {st }}$ century. Moscow: Ad Marginem Press; 2015.

50. Stiglitz J. Great division. Inequality in society, or What is to be done to the remaining $99 \%$ of population: translated from English. Moscow: EKSMO; 2016.

51. Grigoryev I. "Capital” of T. Piketti and "Capital" of Marx. The Economist. 2016; 6:25-34.

52. Aganbegyan A. We've got money! AiF [Internet]. 2016 [cited 2016 Oct 14]. Available from: http://www.aif.ru/ gazeta/number/33135. 